\title{
Analisis Kualitas Pelayanan Pada Kantor Dinas Pendapatan Provinsi Sumatera Utara UPT Medan Selatan
}

\section{Quality Analysis Of Services In The Office Of North Sumatra Province South UPT Medan}

\author{
Azalea Narita AS *, Warjio **, Agus Suryadi*** \\ * Dinas Pendapatan Provinsi Sumatera Utara, \\ **Universitas Sumatera Utara, Indonesia \\ Corresponding author: E-mail: azaleanarita79@yahoo.co.id
}

\begin{abstract}
Abstrak
Tantangan implementasi otonomi daerah yang cukup kompleks mengharuskan daerah harus mau membenahi dirinya agar target-target yang ditetapkan mampu terpenuhi, termasuk dalam upaya pengolahan Pendapatan Asli Daerah (PAD) misalnya pajak daerah yang menjadi kontributor terbesarnya. Dalam segi pelayanan, penerapan strategi pelayanan prima tidak menempatkan masyarakat semata-mata sebagai objek yang dibebani kewajiban, namun harus juga memperoleh kepuasan pelayanan sebagai bagian dari haknya. Melalui berbagai upaya yang berkesinambungan serta terus menerus melakukan perbaikan layanan kepada masyarakat maka penulis tertarik untuk mengkaji penelitian yang berhubungan dengan kualitas pelayanan publik khususnya dalam bidang pembayaran pajak. Penelitian ini menggunakan metode deskriptif yaitu untuk menggambarkan keadaan sebenarnya Bagaimanakah Pelaksanaan Peningkatan Kualitas Pelayanan Publik Pada Samsat Medan Selatan. Dalam penelitian ini, teknik analisis data yang digunakan adalah teknik analisis statistik deskriptif berupa persentase, modus dan median yaitu dengan menjabarkan hasil penelitian sebagaimana adanya. Berdasarkan hasil penelitian Analisis Kualitas Pelayanan Publik melalui Pengukuran Indeks Kepuasan Masyarakat (IKM) yang telah dilakukan pada Dinas Pendapatan Provinsi Sumatera Utara, UPT Medan Selatan dengan menggunakan 14 (empat belas) unsur atau indikator yang didasarkan pada Keputusan Menteri Pendayagunaan Aparatur Negara Nomor 25 Tahun 2004, dapat disimpulkan bahwa kualitas pelayanan publik yang telah dilakukan oleh Dinas Pendapatan Provinsi Sumatera Utara, UPT Medan Selatan adalah Baik.
\end{abstract}

Kata Kunci: Pelayanan, Publik, Kualitas, Indeks Kepuasan

\begin{abstract}
The challenge of implementation of regional autonomy is quite complex requires the region must be willing to fix itself so that the targets set can be fulfilled, including in the effort of processing Pendapatan Asli Daerah (PAD), for example the local tax which became its biggest contributor. In terms of service, the application of the excellent service strategy does not place society solely as an object burdened with obligations, but must also obtain service satisfaction as part of its rights. Through continuous efforts and continuous improvement of services to the public, the authors are interested to examine research related to the quality of public services, especially in the field of tax payments. This study uses descriptive method that is to describe the actual situation How the Implementation of Improving the Quality of Public Service At Samsat South Medan. In this research, data analysis technique used is descriptive statistical analysis technique in the form of percentage, mode and median that is by describing result of research as it is. Based on the results of Quality Analysis of Public Service through Measurement of Public Satisfaction Index (IKM) which has been done on Revenue Service of North Sumatera Province, South Medan UPT using 14 (fourteen) elements or indicators based on Decree of Minister of Administrative Reform Number 25 Year 2004, it can be concluded that the quality of public service that has been done by Revenue Service of North Sumatra Province, South Medan UPT is Good.
\end{abstract}

Keywords: Service, Public, Quality, Satisfaction Index

How to Cite: Narita, A.A.S, Warjio, Agus S, (2016), Analisis Kualitas Pelayanan Pada Kantor Dinas Pendapatan Provinsi Sumatera Utara UPT Medan Selatan, Jurnal Administrasi Publik, 6 (2): 87-96. 


\section{PENDAHULUAN}

Sejalan dengan pasal 18 UUD 1945 dan sesuai dengan otonomi yang diberikan , maka oleh pemerintah pusat, daerah diberikan hak untuk mengurus rumah tangganya sendiri serta diberikan sumber-sumber pendapatan . Tentu tidak mungkin semua sumber-sumber pendapatan itu diberikan kepada daerah, sehingga kepada daerah diberikan sumbersumber keuangan yang dianggap "cukup" dimana salah satu sumber penerimaan yang potensial untuk menopang kemampuan kebutuhan belanja daerah diperoleh dari pajak daerah.

Sebagai konsekuensi perkembangan desentralisasi dan otonomi daerah, khusus sumber-sumber Pajak Daerah ini dibedakan antara Daerah Provinsi dan Daerah Kabupaten/Kota. Sesuai dengan UndangUndang Nomor 28 Tahun 2009 Tentang Pajak Daerah dan Retribusi Daerah. Daerah Provinsi diberikan hak untuk mengelola: 1) Pajak Kenderaan Bermotor dan Pajak Kenderaan di Atas Air, 2) Bea Balik Nama Kenderaan Bermotor dan Kenderaan di Atas Air, 3) Pajak Bahan Bakar Kenderaan Bermotor dan, 4) Pajak Air Permukaan.

Berbagai kebijakan telah dikeluarkan oleh Pemerintah dalam rangka peningkatan kualitas pelayanan publik. Kebijakan untuk meningkatkan kualitas pelayanan publik, sebagaimana diamanatkan dalam Undangundang Republik Indonesia Nomor 25 Tahun 2004 tentang Sistem Perencanaan Pembangunan Nasional (SPPN), dan dengan dikeluarkananya Keputusan Menteri Pendayagunaan Aparatur Negara Nomor 63/KEP/M.PAN/7/2003 Tentang Pedoman Umum Peyelenggaraan Pelayanan Publik dan Keputusan Menteri Pendayagunaan Aparatur Negara Nomor 25/KEP/PAN/2/2004 Tentang Pedoman Umum Penyusunan Indeks Kepuasan Masyarakat Unit Pelayanan Instansi Pemerintah

Untuk meningkatkan kualitas pelayanan, peran, fungsi dan tanggung jawab pemerintah kabupaten/kota perlu diperkuat, karena masyarakat yang akan dilayani berada di kabupaten/kota. Dengan demikian, dalam pelaksanaan pelayanan publik, peran pemerintah daerah kabupaten/kota sangat menonjol. Terhadap beberapa alasan mengapa kualitas pelayanan publik harus semakin ditingkatkan yaitu: 1) Pengguna jasa sektor publik, secara langsung maupun tidak langsung telah membayar imbalan atas jasa yang diterima atau dibutuhkan. Pembayaran secara langsung berbentuk biaya administratif, sedangkan yang tidak langsung berupa retribusi, 2) Aparatur Negara sebagai abdi masyarakat telah menerima imbalan (gaji) atas tugasnya memberikan jasa pelayanan, 3) Sesuai landasan normatif, baik berupa Undang-Undang Pokok Kepegawaian, maupun Panca Prasetya Korps Pegawai Republik Indonesia, telah ditegaskan bahwa aparatur Negara adalah abdi masyarakat.

\section{METODE PENELITIAN}

Kajian kepustakaan adalah suatu proses yang dilalui untuk mendapatkan teori terdahulu dengan cara mencari kepustakaan yang berhubungan dengan masalah penelitian. Telaah kepustakaan digunakan untuk menelusuri penelitian terdahulu berhubungan dengan masalah penelitian, sehingga dapat mengetahui masalah mana yang belum diteliti secara mendalam oleh peneliti terdahulu. Selain itu, juga sebagai perbandingan antara fenomena yang hendak diteliti dengan hasil studi terdahulu yang serupa.

Pelayanan publik yang modelnya birokratis cocok untuk budaya masyarakat hirarkhis; pelayanan publik yang modelnya Privatisasi cocok untuk budaya masyarakat individual (yang anti hirarkhis); pelayanan publik yang modelnya kolektif cocok untuk budaya masyarakat fatalis (yang mendukung budaya hirarkhis dan anti budaya individu); sedangkan pelayanan publik yang modelnya memerlukan pelayanan cepat dan terbuka cocok untuk budaya masyarakat egaliter 
(yang anti budaya hirarkhis, anti budaya individu dan anti budaya fatalis).

Pelayanan yang berkualitas sangat tergantung pada berbagai aspek, yaitu bagaimana pola penyelenggaraannya (tata laksana), dukungan sumber daya manusia, dan kelembagaan. Dilihat dari sisi pola penyelenggaraannya, pelayanan publik masih memiliki berbagai kelemahan antara lain: a) Kurang responsif. Kondisi ini terjadi pada hampir semua tingkatan unsur pelayanan, mulai pada tingkatan petugas pelayanan (front line) sampai dengan tingkatan penanggungjawab instansi, b) Kurang informatif. Berbagai informasi yang seharusnya disampaikan kepada masyarakat, lambat atau bahkan tidak sampai kepada masyarakat, c) Kurang accessible, berbagai unit pelaksana pelayanan terletak jauh dari jangkauan masyarakat, sehingga menyulitkan bagi mereka yang memerlukan pelayanan tersebut. d) Kurang koordinasi. Berbagai unit pelayanan yang terkait satu dengan lainnya sangat kurang berkoordinasi, e) Birokratis. Pelayanan (khususnya pelayanan perijinan) pada umumnya dilakukan dengan melalui proses yang terdiri dari berbagai level, sehingga menyebabkan penyelesaian pelayanan yang terlalu lama, f) Kurang mau mendengar keluhan/saran/aspirasi masyarakat. Pada umumnya aparat pelayanan kurang memiliki kemauan untuk mendengar keluhan/saran/aspirasi dari masyarakat, g) Inefisien. Berbagai persyaratan yang diperlukan (khususnya dalam pelayanan perijinan) seringkali tidak relevan dengan pelayanan yang diberikan.

Dilihat dari sisi sumber daya manusianya, kelemahan utamanya adalah berkaitan dengan profesionalisme, kompetensi, empathy dan etika. Berbagai pandangan juga setuju bahwa salah satu dari unsur yang perlu dipertimbangkan adalah masalah sistem kompensasi yang tepat.

Dilihat dari sisi kelembagaan, kelemahan utama terletak pada disain organisasi yang tidak dirancang khusus dalam rangka pemberian pelayanan kepada masyarakat, penuh dengan hirarki yang membuat pelayanan menjadi berbelit-belit (birokratis), dan tidak terkoordinasi. Kecenderungan untuk melaksanakan dua fungsi sekaligus, fungsi pengaturan dan fungsi penyelenggaraan, masih sangat kental dilakukan oleh pemerintah, yang juga menyebabkan pelayanan publik menjadi tidak efisien.

\section{HASIL DAN PEMBAHASAN}

Substansi pelayanan publik selalu dikaitkan dengan suatu kegiatan yang dilakukan oleh seseorang atau kelompok orang atau instansi tertentu untuk memberikan bantuan dan kemudahan kepada masyarakat dalam rangka mencapai tujuan tertentu. Pelayanan publik ini menjadi semakin penting karena senantiasa berhubungan dengan khalayak masyarakat ramai yang memiliki keaneka ragaman kepentingan dan tujuan. Oleh karena itu institusi pelayanan publik dapat dilakukan oleh pemerintah maupun non-pemerintah. Jika pemerintah, maka organisasi birokrasi pemerintahan merupakan organisasi terdepan yang berhubungan dengan pelayanan publik. Dan jika non-pemerintah, maka dapat berbentuk organisasi partai politik, organisasi keagamaan, lembaga swadaya masyarakat maupun organisasi-organisasi kemasyarakatan yang lain.

Dalam tinjauan manajemen pelayanan publik, ciri struktur birokrasi yang terdesentralisir memiliki beberapa tujuan dan manfaat antara lain: (1) Mengurangi (bahkan menghilangkan) kesenjangan peran antara organisasi pusat dengan organisasiorganisasi pelaksana yang ada dilapangan, (2) Melakukan efesiensi dan penghematan alokasi penggunaan keuangan, (3) Mengurangi jumlah staf/aparat yang berlebihan terutama pada level atas dan level menengah (prinsip rasionalisasi), (4) Mendekatkan birokrasi dengan masyarakat pelanggan 
Begitu pentingnya profesionalisasi pelayanan publik ini, pemerintah melalui Menteri Negara Pendayagunaan Aparatur Negara telah mengeluarkan suatu kebijaksanaan Nomor 63/KEP/M.PAN/7/2003 tentang Pedoman Umum Penyelenggaraan Pelayanan Publik yang perlu dipedomani oleh setiap birokrasi publik dalam memberikan pelayanan kepada masyarakat berdasar prinsip-prinsip pelayanan sebagai berikut: Kesederhanaan, Kejelasan, Kepastian Waktu, Akurasi, Keamanan, Tanggung jawab, Kelengkapan sarana dan prasarana, Kemudahan Akses, Kedisiplinan, Kesopanan dan Keramahan, Kenyamanan

Demikian juga dalam pelayanan jasa lainnya, kepercayaan sesuatu yang dapat membuat citra positif di mata publik. Karena itu, jika petugas semakin adil, memberikan kemudahan, handal, nyaman memberikan pelayanan serta peduli, maka akan semakin tinggi kepercayaan masyarakat (high trust) kepada penyedia layanan. Tetapi jika publik sudah kehilangan kepercayaan sulit membina ulang. Sebab krisis kepercayaan dapat dianalogikan dengan "virus penyakit" yang apabila tidak diobati dengan cepat dan tepat, akan "berkembang biak" sedemikian rupa sehingga upaya mengobatinya akan menjadi lebih sulit. Demikian juga halnya dengan krisis yang tidak cepat diatasi akan melahirkan krisis baru yang apabila tidak diatasi akan melahirkan krisis multidimensi, dan apabila tidak diatasi dengan segera tidak mustahil akan terjadi keresahan di masyarakat. Tegasnya, tidak menjaga kepercayaan berarti akan menimbulkan kekecewaan rakyat yang pada gilirannya mungkin berakibat timbulnya krisis kepercayaan kepada pemerintah. Dimensi kepercayaan ini dapat diberi tanda (1) membedakan baik/buruk, membedakan benar/salah, (3) pantas/tidak pantas, (4) wajar/tidak wajar, (5) Pencegahan menyimpangan (antisipasi); (6) mendeteksi perubahan.
Keenam dimensi kualitas pelayanan publik yang dirumuskan penulis disebut model "enam Ke" (keadilan, kemudahan, kepedulian, kehandalan, kenyamanan, kepercayaan). Keenam dimensi ini saling berhubungan satu sama lain dan tidak bisa dipisahkan, "enam Ke" bila diibaratkan dengan roda mobil yang memiliki 6 sekerup (ulir, baut) untuk mengunci roda, ke enam sekerup ini mempunyai posisi dan peran yang sama (satu kelas). Maju mundurnya roda pemerintahan tergantung kepada "enam Ke", jika salah satu sekerupnya yaitu keadilan dilepas atau berpura-pura dipasang, dan roda terus dipaksakan berjalan maka lambat laun citra pemerintah akan rusak. Sebab, bagaimanapun sekerup lainnya akan terpengaruh seperti sekerup kepercayaan, yang pada gilirannya publik akan kehilangan kepercayaan, karena pelayanan itu penuh primordialisme, diskriminatif dan sarat person. Primordialisme dan diskriminasi pasti akan membuka ruang terbangunnya korupsi, kolusi dan nepotisme. Karena itu, "enam Ke" adalah satu kesatuan yang utuh (sistemik), sehingga roda pemerintahan dapat melaju kencang untuk memberikan pelayanan yang terbaik kepada masyarakat.

Model tersebut dapat disajikan dalam gambar di bawah ini:

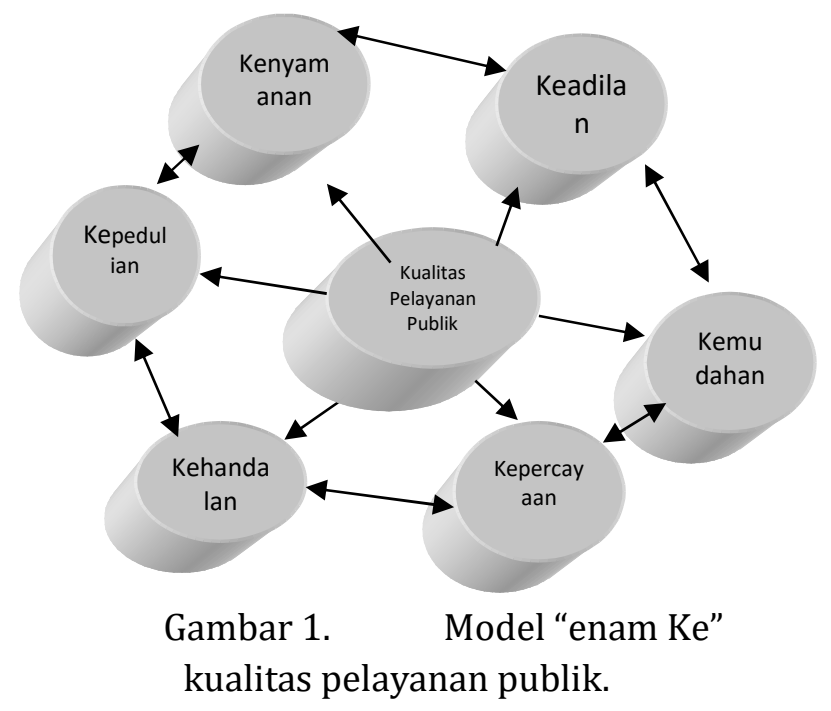

Mengingat luasnya wilayah kerja Dinas Pendapatan Provinsi Sumatera Utara yang meliputi seluruh wilayah Sumatera Utara 
maka dibentuklah Unit Pelaksana Teknis Dinas untuk efisiensi dan efektifitas pelaksanaan tupoksinya. Sampai dengan tanggal 31 Desember 2013, Dinas Pendapatan Provinsi Sumatera Utara memiliki 34 UPT yang terdiri dari 32 UPT/Samsat yang tersebar di hampir seluruh kabupaten/kota di Sumatera Utara serta 1 UPT Penyuluhan dan 1 UPT Pusat Informasi Pendapatan Daerah (PIPD), 10 lokasi samsat gerai, 17 unit bus samsat keliling, 2 lokasi samsat mall dan 1 lokasi samsat drive thru. Ke depan, Dinas Pendapatan Provinsi Sumatera Utara akan terus berinovasi meningkatkan sumber daya serta sarana prasarana guna mendekatkan pelayanan kepada masyarakat. Diharapkan dengan banyaknya lokasi pembayaran pajak, dapat memudahkan masyarakat dalam membayar pajak kendaraan bermotor, meningkatkan pelayanan serta akhirnya akan meningkatkan pendapatan daerah.

Perkembangan penerimaan Pendapatan Asli Daerah (PAD) Provinsi Sumatera Utara tahun 2009 sampai dengan tahun 2013 sebagai berikut:

Tabel 4.4. Target Realisasi Pajak Daerah Tahun 2009-2013

\begin{tabular}{lllll}
\hline No & Tahun & Target & Realisasi & $\%$ \\
\hline 1 & 2009 & $1.946 .447 .000 .000,00$ & $1.834 .682 .281 .195,00$ & 94,26 \\
2 & 2010 & $2.204 .109 .225 .000,00$ & $2.271 .474 .933 .653,00$ & 103,06 \\
3 & 2011 & $3.097 .600 .000 .000,00$ & $3.141 .123 .907 .437,50$ & 101,41 \\
4 & 2012 & $3.835 .407 .768 .128,00$ & $3.636 .074 .646 .214,00$ & 94,80 \\
5 & 2013 & $4.519 .706 .265 .924,00$ & $3.685 .668 .756 .991,00$ & 81,55 \\
\hline
\end{tabular}

Dari tabel di atas terlihat bahwa realisasi pencapaian target PAD tahun 20092013 rata-rata 96,14\% per tahun. Realisasi pencapaian target secara keseluruhan cukup memuaskan. Namun demikian, bila kita cermati prosentase realisasi PAD yang dikelola Dinas Pendapatan Provinsi Sumatera Utara, pada tahun 2012 dan 2013 terdapat penurunan yang cukup signifikan.

Berdasarkan hasil analisis, diketahui bahwa penyebab utama penurunan capaian tersebut adalah berkurangnya pendapatan dari sektor Bea Balik Nama Kendaraan Bermotor I (BBN-KB I) hal ini dikarenakan adanya kebijakan dari Pemerintah bahwa down payment untuk pembelian kendaraan dengan skema kredit yaitu sebesar 30\% sehingga masyarakat menunda untuk membeli kendaraan. Selain itu, kurangnya kesadaran masyarakat dalam membayar pajak juga turut andil dalam penurunan PAD.

Tabel 4.5. Target Realisasi Retribusi Daerah Tahun 2009-2013

\begin{tabular}{lllll}
\hline No & Tahun & Target & Realisasi & $\%$ \\
\hline 1 & 2009 & 25.562 .581 .000 & 29.456 .735 .843 & 115,23 \\
2 & 2010 & 52.100 .607 .052 & 35.811 .313 .910 & 68,73 \\
3 & 2011 & 21.167 .043 .590 & 31.297 .593 .623 & 147,86 \\
4 & 2012 & 39.171 .451 .121 & 33.494 .627 .707 & 85,51 \\
5 & 2013 & 44.171 .451 .121 & 7.652 .445 .911 & 17,32 \\
\hline
\end{tabular}

Dari tabel di atas terlihat bahwa realisasi pencapaian target retribusi daerah tahun 2009-2013, dimana tidak terjadi peningkatan realisasi di tiap tahun nya, dengan rata-rata realisasi sebesar 95,62\%. Realisasi pencapaian target secara keseluruhan cukup memuaskan. 
Tabel 4.6. Target Realisasi Pendapatan Denda Pajak Tahun 2009-2013

\begin{tabular}{lllll}
\hline No & Tahun & Target & Realisasi & $\%$ \\
\hline 1 & 2009 & 39.383 .035 .180 & 78.464 .892 .995 & 199,24 \\
2 & 2010 & 118.384 .031 .641 & 90.671 .693 .591 & 76,59 \\
3 & 2011 & 70.989 .012 .855 & 124.598 .600 .915 & 175,52 \\
4 & 2012 & 177.478 .929 .961 & 127.476 .107 .423 & 71,83 \\
5 & 2013 & 207.900 .960 .000 & 51.631 .607 .115 & 24,84 \\
\hline
\end{tabular}

Dari tabel di atas terlihat bahwa realisasi dari pencapaian target pengelolaan lain-lain PAD yang sah tahun 2009-2013 dimana realisasi tahun 2009, dan 2011 dapat terealisasi di atas target (surplus), kecuali tahun 2010, tahun 2012 dan tahun 2013.
Adapun rincian perkembangan penerimaan PAD Provinsi Sumatera Utara tahun 2009 sampai dengan tahun 2013 yang meliputi Pajak kendaraan Bermotor (PKB), Bea Balik Nama Kendaraan Bermotor (BBNKB), Pajak Bahan Bakar Kendaraan Bermotor (PBB-KB), Pajak Air Bawah Tanah dan Air Permukaan, sebagai berikut:

Tabel 4.7. Target Realisasi Pajak Kendaraan Bermotor (PKB) Tahun 2009-2013

\begin{tabular}{lllll}
\hline No & Tahun & Target & Realisasi & $\%$ \\
\hline 1 & 2009 & 714.971 .300 .000 & 739.202 .038 .400 & 103,39 \\
2 & 2010 & 832.971 .300 .000 & 799.444 .270 .412 & 95,98 \\
3 & 2011 & 1.000 .991 .000 .000 & 1.046 .727 .575 .214 & 104,57 \\
4 & 2012 & 1.199 .237 .457 .346 & 1.211 .376 .190 .415 & 101,01 \\
5 & 2013 & 1.340 .999 .154 .059 & 1.322 .588 .375 .143 & 98,63 \\
\hline
\end{tabular}

Tabel 4.8. Target Realisasi Bea Balik Nama Kendaraan Bermotor (BBN-KB) Tahun 20092013

\begin{tabular}{lllll}
\hline No & Tahun & Target & Realisasi & $\%$ \\
\hline 1 & 2009 & 797.925 .700 .000 & 643.026 .034 .810 & 80,59 \\
2 & 2010 & 818.987 .925 .000 & 963.572 .410 .240 & 117,65 \\
& & & 1.533 .366 .072 .1 & 110,66 \\
3 & 2011 & 1.385 .609 .000 .000 & 93 & \\
4 & 2012 & 1.831 .170 .310 .782 & $\begin{array}{l}1.808 .944 .474 .1 \\
4\end{array}$ & 98,79 \\
5 & 2013 & 2.133 .207 .111 .865 & 1.642 .093 .100 .0 & 76,98 \\
\hline
\end{tabular}


Tabel 4.9. Target Realisasi Pajak Bahan Bakar Kendaraan Bermotor (PBB-KB) Tahun 2009-2013

\begin{tabular}{lllll}
\hline NO & TAHUN & TARGET & REALISASI & $\%$ \\
\hline 1 & 2009 & 410.000 .000 .000 & 426.389 .377 .186 & 104,00 \\
2 & 2010 & 526.000 .000 .000 & 480.348 .466 .722 & 91,32 \\
3 & 2011 & 697.500 .000 .000 & 539.657 .139 .592 & 77,37 \\
4 & 2012 & 755.000 .000 .000 & 587.582 .131 .614 & 77,83 \\
5 & 2013 & 962.500 .000 .000 & 682.716 .876 .960 & 70,93 \\
\hline
\end{tabular}

Dari tabel di atas terlihat bahwa prosentase realisasi PBB-KB selalu mengalami penurunan setiap tahunnya. Namun bila kita cermati realisasi riilnya, penerimaan PBB-KB mengalami peningkatan yang cukup baik.
Sulitnya mendapatkan data riil dari vendor terkait penyaluran BBM mengakibatkan penetapan target yang kurang akurat. Begitu juga halnya dengan target realisasi Pajak Air Permukaan.

Tabel 4.10. Target Realisasi Pajak Air Permukaan Tahun 2009-2013

\begin{tabular}{lllll} 
No & Tahun & Target & Realisasi & $\%$ \\
\hline 1 & 2009 & $23.500 .000 .000,00$ & $26.017 .746 .423,00$ & 110,71 \\
2 & 2010 & $26.100 .000 .000,00$ & $28.063 .429 .334,00$ & 107,52 \\
3 & 2011 & $13.500 .000 .000,00$ & $21.372 .670 .438,50$ & 158,32 \\
4 & 2012 & $50.000 .000 .000,00$ & $28.171 .850 .002,00$ & 56,34 \\
5 & 2013 & $83.000 .000 .000,00$ & $38.270 .404 .874,00$ & 46,11 \\
\hline
\end{tabular}

Dinas Pendapatan Provinsi Sumatera Utara, dalam melaksanaan tugas dan fungsi agar dapat mencapai tujuan dan sasaran yang ditetapkan setiap tahunnya dalam program jangka pendek maupun jangka panjang perlu melakukan langkah-langkah yang dapat dijadikan sebagai tantangan dalam pelayanan antara lain: 1) Perlu meningkatkan kualitas kegiatan pengelolaan pajak daerah dan retribusi daerah; 2) Pembuatan media untuk mensosialisasikan pajak provinsi; 3) Perlu melakukan penyusunan instrumen monitoring, evaluasi dan pelaporan pendapatan pajak provinsi; 4) Merancang kebijakan, program dan kegiatan intensifikasi; 5) Melaksanakan upaya penegakan sanksi hukum (law enforcement) baik dalam hal disiplin adminstrasi dan kepatuhan dalam pungutan dan keterlambatan pembayaran/penyetoran.

Pada hasil analisis ini disajikan hasil perhitungan kinerja pelayanan secara keseluruhan (seperti terlihat pada Tabel di bawah ini) berdasarkan dari bobot masingmasing unsur yang dinilai. 
Azalea Narita AS, Warjio, Agus Suryadi, Analisis Kualitas Pelayanan Pada Kantor Dinas

Tabel 4.38. Hasil Analisis kinerja pelayanan

\begin{tabular}{|c|c|c|c|c|}
\hline No. & Unsur Pelayanan & Bobot & Rata-rata & Keterangan \\
\hline 1. & Prosedur pelayanan & 364 & 2.43 & Kurang baik \\
\hline \multirow[t]{3}{*}{2.} & Persyaratan pelayanan & 346 & 2.30 & Kurang baik \\
\hline & Persyaratan pengurusan administrasi & 357 & 2.38 & Kurang mudah \\
\hline & Persyaratan pengaduan dan komplain & 335 & 2.23 & Kurang mudah \\
\hline \multirow[t]{3}{*}{3.} & Kejelasan petugas pelayanan & 379.5 & 2.53 & Baik \\
\hline & $\begin{array}{l}\text { Kejelasan/keberadaan petugas layanan } \\
\text { dalam melayani administrasi }\end{array}$ & 389 & 2.59 & Jelas \\
\hline & $\begin{array}{l}\text { Kejelasan/keberadaan petugas layanan } \\
\text { dalam melayani pengaduan dan complain }\end{array}$ & 370 & 2.47 & Jelas \\
\hline \multirow[t]{5}{*}{4.} & Kedisiplinan petugas pelayanan & 359.75 & 2.4 & Kurang baik \\
\hline & $\begin{array}{l}\text { Kedisiplinan petugas dalam melayani } \\
\text { masyarakat }\end{array}$ & 366 & 2.44 & Kurang disiplin \\
\hline & $\begin{array}{l}\text { Ketepatan waktu petugas pelayanan } \\
\text { datang }\end{array}$ & 344 & 2.29 & Kurang tepat \\
\hline & $\begin{array}{l}\text { Ketepatan waktu petugas pelayanan } \\
\text { pulang }\end{array}$ & 357 & 2.38 & Kurang tepat \\
\hline & $\begin{array}{l}\text { Kepatuhan petugas pelayanan terhadap } \\
\text { prosedur }\end{array}$ & 372 & 2.48 & Kurang patuh \\
\hline \multirow[t]{3}{*}{5.} & Tanggung jawab petugas pelayanan & 420 & 2.79 & Baik \\
\hline & $\begin{array}{l}\text { Tanggungjawab petugas dalam melayani } \\
\text { administrasi }\end{array}$ & 427 & 2.85 & $\begin{array}{l}\text { Bertanggung } \\
\text { jawab }\end{array}$ \\
\hline & $\begin{array}{l}\text { Tanggungjawab petugas dalam melayani } \\
\text { pengaduan/complain }\end{array}$ & 413 & 2.75 & $\begin{array}{l}\text { Bertanggung } \\
\text { jawab }\end{array}$ \\
\hline \multirow[t]{3}{*}{6.} & Kemampuan petugas pelayanan & 411 & 2.74 & Baik \\
\hline & $\begin{array}{l}\text { Kemampuan petugas dalam melayani } \\
\text { masyarakat }\end{array}$ & 420 & 2.8 & Mampu \\
\hline & $\begin{array}{l}\text { Kemampuan petugas dalam melayani } \\
\text { pengadua/komplain }\end{array}$ & 402 & 2.68 & Mampu \\
\hline \multirow[t]{3}{*}{7.} & Kecepatan pelayanan & 367 & 2.43 & Kurang baik \\
\hline & $\begin{array}{l}\text { Ketepatan waktu dalam melayani } \\
\text { administrasi }\end{array}$ & 365 & 2.43 & Kurang tepat \\
\hline & $\begin{array}{l}\text { Ketepatan waktu dalam menyelesaikan } \\
\text { pengurusan administrasi sesuai prosedur }\end{array}$ & 369 & 2.46 & Kurang tepat \\
\hline 8. & Keadilan mendapatkan pelayanan & 358 & 2.39 & Kurang baik \\
\hline 9. & Kesopanan dan keramahan petugas & 429 & 2.86 & Baik \\
\hline 10. & Kewajaran biaya pelayanan & 393 & 2.62 & Baik \\
\hline 11. & Kepastian biaya pelayanan & 327 & 2.18 & Kurang baik \\
\hline \multirow[t]{3}{*}{12.} & Kepastian jadwal pelayanan & 370.5 & 2.47 & Kurang baik \\
\hline & Kepastian jadwal buka pelayanan & 360 & 2.4 & Kurang pasti \\
\hline & Kepastian jadwal tutup pelayanan & 381 & 2.54 & Pasti \\
\hline \multirow[t]{4}{*}{13.} & Kenyamanan lingkungan & 374 & 2.49 & Kurang baik \\
\hline & Kenyamanan ruang tunggu & 398 & 2.65 & Nyaman \\
\hline & Kenyamanan tempat parkir & 343 & 2.29 & Kurang nyaman \\
\hline & Kenyamanan kantin & 381 & 2.54 & Nyaman \\
\hline \multirow[t]{4}{*}{14.} & Keamanan Pelayanan & 421.33 & 2.81 & Baik \\
\hline & Keamanan ruang tunggu & 430 & 2.87 & Aman \\
\hline & Keamanan tempat parkir & 405 & 2.7 & Aman \\
\hline & Keamanan kantin & 429 & 2.86 & Aman \\
\hline \multicolumn{2}{|c|}{ Rata-rata keseluruhan } & 353.8 & 2.54 & Baik \\
\hline
\end{tabular}

(Sumber : Rekapitulasi Hasil Penelitian) 
Pada Tabel ini disajikan hasil perhitungan nilai Indeks Kepuasan Masyarakat pada Dinas Pendapatan Provinsi Sumatera Utara, UPT Medan Selatan sebagai berikut :

Tabel 4.39. Perhitungan kualitas pelayanan pada Dinas Pendapatan Provinsi Sumatera Utara, UPT Medan Selatan

\begin{tabular}{|c|c|c|c|c|c|}
\hline No. & Unsur Pelayanan & $\begin{array}{l}\text { Nilai } \\
\text { Unsur } \\
\text { Pelayanan }\end{array}$ & $\begin{array}{l}\text { Kualitas Unit } \\
\text { Pelayanan }\end{array}$ & $\begin{array}{l}\text { Bobot nilai rata- } \\
\text { rata tertimbang }\end{array}$ & $\begin{array}{l}\text { Jumlah } \\
(3 \times 5)\end{array}$ \\
\hline 1 & 2 & 3 & 4 & 5 & 6 \\
\hline 1. & Prosedur pelayanan & 2.43 & Kurang baik & 0.071 & 0.17 \\
\hline 2. & Persyaratan pelayanan & 2.30 & Kurang baik & 0.071 & 0.16 \\
\hline 3. & $\begin{array}{l}\text { Kejelasan } \\
\text { petugas pelayanan }\end{array}$ & 2.53 & Baik & 0.071 & 0.18 \\
\hline 4. & $\begin{array}{l}\text { Kedisiplinan petugas } \\
\text { pelayanan }\end{array}$ & 2.4 & Kurang baik & 0.071 & 0.17 \\
\hline 5. & $\begin{array}{l}\text { Tanggung jawab } \\
\text { petugas pelayanan }\end{array}$ & 2.79 & Baik & 0.071 & 0.20 \\
\hline 6. & $\begin{array}{l}\text { Kemampuan petugas } \\
\text { pelayanan }\end{array}$ & 2.74 & Baik & 0.071 & 0.20 \\
\hline 7. & Kecepatan pelayanan & 2.43 & Kurang baik & 0.071 & 0.17 \\
\hline 8. & $\begin{array}{l}\text { Keadilan mendapatkan } \\
\text { pelayanan }\end{array}$ & 2.39 & Kurang baik & 0.071 & 0.17 \\
\hline 9. & $\begin{array}{l}\text { Kesopanan dan } \\
\text { keramahan petugas }\end{array}$ & 2.86 & Baik & 0.071 & 0.21 \\
\hline 10. & $\begin{array}{l}\text { Kewajaran } \\
\text { pelayanan }\end{array}$ & 2.62 & Baik & 0.071 & 0.19 \\
\hline 11. & $\begin{array}{l}\text { Kepastian } \\
\text { pelayanan }\end{array}$ & 2.18 & Kurang baik & 0.071 & 0.15 \\
\hline 12. & $\begin{array}{l}\text { Kepastian jadwal } \\
\text { pelayanan }\end{array}$ & 2.47 & Kurang baik & 0.071 & 0.18 \\
\hline 13. & $\begin{array}{l}\text { Kenyamanan } \\
\text { lingkungan }\end{array}$ & 2.49 & Kurang baik & 0.071 & 0.18 \\
\hline 14. & Keamanan Pelayanan & 2.81 & Baik & 0.071 & 0.21 \\
\hline \multicolumn{5}{|c|}{ Nilai IKM } & 2.54 \\
\hline \multicolumn{5}{|c|}{ Nilai indeks } & 63.5 \\
\hline \multicolumn{5}{|c|}{ Kualitas pelayanan } & Baik \\
\hline
\end{tabular}

(Sumber : Rekapitulasi Hasil Penelitian)

\section{SIMPULAN}

Berdasarkan hasil penelitian Analisis Kualitas Pelayanan Publik melalui Pengukuran Indeks Kepuasan Masyarakat (IKM) yang telah dilakukan pada Dinas Pendapatan Provinsi Sumatera Utara, UPT Medan Selatan dengan menggunakan 14 (empat belas) unsur atau indikator yang didasarkan pada Keputusan Menteri Pendayagunaan Aparatur Negara Nomor 25 Tahun 2004, dapat disimpulkan bahwa kualitas pelayanan publik yang telah dilakukan oleh Dinas Pendapatan Provinsi Sumatera Utara, UPT Medan Selatan adalah Baik.
Berikut ini adalah unsur pelayanan dengan kualitas baik: Kejelasan/keberadaan petugas layanan dalam melayani administrasi, Kejelasan/keberadaan petugas layanan dalam melayani pengaduan dan komplain, Tanggungjawab petugas dalam melayani administrasi, Tanggungjawab petugas dalam melayani pengaduan/komplain, Kemampuan petugas dalam melayani masyarakat, Kemampuan petugas dalam melayani pengadua/complain, Kesopanan dan keramahan petugas, Kewajaran biaya pelayanan, Kepastian jadwal tutup pelayanan, Kenyamanan ruang tunggu, Kenyamanan kantin, Keamanan ruang tunggu, Keamanan tempat parker, Keamanan kantin. 


\section{DAFTAR PUSTAKA}

Gibson, James.L., John M.Ivancevich., dan James H. Donelli. 1997. Organisasi Jilid 1 dan 2. (Terjemahan Nunuk Adiarni). Jakarta : Binarupa Aksara.

Handoko, Hani T. 1998. Manajemen. Edisi ke-2. Yogyakarta : BPFE

Hasibuan, Pelayu. 2001 Manajemen Sumber Daya Manusia. Jakarta: Binarupa Aksara

Jasfar. Farida. 2005. Manajemen Jasa Pendekatan Terpadu. Jakarta: Ghalia Indonesia.

Jauch,L.R: Glueck,W.F 1998. Manajemen Strategis dan Kebijakan Perusahaan. Jakarta : Penerbit Erlangga

Kotler Philip. 1997. Manajemen Pemasaran. Analisis Perencanaan, Implementasi, dan Kontrol. Alih bahasa Hendra Teguh dkk. Jakarta : PT. Dadi Kayana Abadi.

Kuncoro,M, 2006. Strategi Bagaimana Meraih Keunggulan Kompetitif? Jakarta: Penerbit Erlangga

Loether J. Herman., and McTavish,G. Donald. 1993. Descriptive and Inferential Statistics An Introduction. Boston : A Division of Simon Schuster, Inc

Mc Kevit David. 1998. Managing Core Public Service. Massachuselts : Blackwell Publishers

Ndraha, Taliziduhu.1997. Metodologi Ilmu Pemerintahan. Jakarta: Rineka Cipta.

-----.-2003. Kybernology (Ilmu Pemerintahan Baru) jilid I . Jakarta : Rineka Cipta.

-------2005. Kybernology, Beberapa Konstruksi Utama, Tangerang: Cirao Credentia Centre.

Nisjar,K: Winardi,1997. Manajemen Strategik. Bandung : Penerbit Mandar Maju.

Pasolong, Harbani. 2007. Teori Administrasi Publik. Bandung : ALFABETA.

Robbins, Stepen. 1994. Teori Organisasi: Struktur, Desain dan Aplikasi. Edisi Ketiga. Terjemahan Jusuf Udaya Lic. Jakarta : Arcan

Rosenbloom, David, H., Ingraham, Patricia, W., 1992. The Promise and Paradox of Civil Service. Pittsburgh : University of Pittsburgh

Saefullah. Djadja.H.A. 2007. Pemikiran Kontemporer Administrasi Publik Perspektif Manajemen Sumber Daya Manusia Dalam Era Desentralisasi. Cetakan pertama. Bandung : LP3AN FISIP UNPAD

Siagian. Sondang P. 2001.a. Kerangka Dasar Ilmu Administrasi. Jakarta : Rineka Cipta

------2001.b. Administrasi Pembangunan Konsep, Dimensi dan Strateginya. Jakarta : Bumi Aksara

2006. Filsafat Ilmu Administrasi. Jakarta : Bumi Aksara

Siagian, Matias. (2011). Metode Penelitian Sosial. Medan: PT Grasindo Monoratama.
Siagian dan Suriadi. (2010). Tanggung Jawab Sosial Perusahaan CSR Perspektif Pekerjaan Sosial. Medan: FISP USU Press.

Singarimbun, Masri dan Sofyan Effendi. 1989. Metode Penelitian Survey. Jakarta : LP3ES

Sitorus Monang. 2009. Manajemen Pelayanan Publik. Bandung : Unpad Press

Wahyudi,A.S, 1996, Manajemen Strategi: Pengantar Proses Berpikir Strategik, Jakarta: Penerbit Binarupa Aksara

Winardi 1999. Pengantar Tentang Teori Sistem dan Analisis Sistem. Bandung: Mandar Maju Pemikiran Sistematik dalam Organisasi dan Manajemen. Jakarta : Rajawali Pers

Van Meter, D.S. and C.E. Van Horn. 1974. The Policy Implementation Process: A Conceptual Framework Administration and Society 6.

Undang-Undang dan Peraturan

Undang-Undang No 22 Tahun 1999 tentang Pemerintahan Daerah

Undang-Undang Nomor 32 Tahun 2004 tentang Pemerintahan Daerah.

Undang-Undang No 14 Tahun 2008 tentang Keterbukaan Informasi Publik

Undang-Undang Nomor 18 Tahun 1997 Tentang Pajak Daerah dan Retribusi Daerah

Undang-Undang Republik Indonesia Nomor 25 Tahun 2004 tentang Sistem Perencanaan Pembangunan Nasional

Undang-Undang No 37 Tahun 2008 tentang Ombusman Republik Indonesia.

Undang-Undang No.25 Tahun 2009 tentang Pelayanan Publik

Keputusan Menteri Pendayagunaan Aparatur Negara Nomor 63/KEP/ M.PAN/7/2003 Tentang Pedoman Umum Penyelenggaraan Pelayanan Publik 